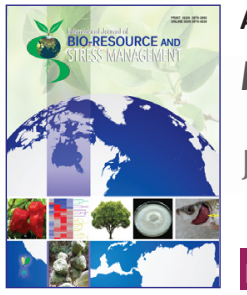

\title{
Gap Analysis and Economics of Front Line Demonstrations in Chickpea (Cicer arietinum L.) under Humid South Eastern Plain Zone of Rajasthan
}

\author{
R. K. Shivran ${ }^{1}$, Rajesh Kumar ${ }^{1}$, Ummed Singh ${ }^{2}$ and C. S. Praharaj ${ }^{3}$ \\ ${ }^{1}$ Agricultural Research Station, Ummedganj, Agriculture University, Kota, Rajasthan (324 001), India \\ ${ }^{2}$ Agriculture University, Jodhpur, Rajasthan (342 304), India \\ ${ }^{3}$ ICAR-Indian Institute of Pulses Research, Kanpur, Uttar Pradesh (208 024), India
}

\section{Open Access \\ Corresponding Author \\ Ummed Singh \\ e-mail: singhummed@yahoo.co.in}

Citation: Shivran et al., 2020. Gap Analysis and Economics of Front Line Demonstrations in Chickpea (Cicer arietinum L) under Humid South Eastern Plain Zone of Rajasthan. International Journal of Bio-resource and Stress Management 2020, 11(3), 258-263. HTTPS://DOI.ORG/10.23910/1.2020.2100.

Copyright: (c) 2020 Shivran et al. This is an open access article that permits unrestricted use, distribution and reproduction in any medium after the author(s) and source are credited.

Data Availability Statement: Legal restrictions are imposed on the public sharing of raw data. However, authors have full right to transfer or share the data in raw form upon request subject to either meeting the conditions of the original consents and the original research study. Further, access of data needs to meet whether the user complies with the ethical and legal obligations as data controllers to allow for secondary use of the data outside of the original study.

Conflict of interests: The authors have declared that no conflict of interest exists.

Acknowledgements: The financial support to meet the expenses towards frontline demonstrations by Department of Agricultural \& Farmers Welfare, Government of India through its nodal agency ICAR- Indian Institute of Pulses Research, Kanpur is gratefully acknowledged.

\begin{abstract}
Performance of improved production technologies of chickpea vis-à-vis farmers' practice was evaluated through front line demonstrations at farmer's field during winter seasons starting from October 2007 to April 2008, October 2008 to April 2009 and October 2009 to April 2010 by Agricultural Research Station, Kota. Recommended technologies for the agro-climatic zone developed by the university were adopted in letter and spirit for raising chickpea. Newly released improved varieties of chickpea viz., GNG-663 and GNG-469 were grown under demonstrations. Selection of farmers was done on the basis of Participatory Rural Appraisal (PRA). The results indicated that average yield under improved technology ranged from 1773 to $1907 \mathrm{~kg} \mathrm{ha}^{-1}$ with a mean of $1832 \mathrm{~kg} \mathrm{ha}^{-1}$. In per cent terms, scaling in productivity following improved technology ranged from 10.20 to $17.74 \%$ with an average value of $14.72 \%$ (over the Farmers' practice). The average yield gaps for technology, extension and technology index were $568,231 \mathrm{~kg} \mathrm{ha}^{-1}$ and $12.78 \%$, respectively. Improved technologies also enhanced average gross ( $₹ 42,639 \mathrm{ha}^{-1}$ ), net return ( $\left.₹ 30,087 \mathrm{ha}^{-1}\right)$, effective gain ( $₹ 3,362$ $\left.\mathrm{ha}^{-1}\right)$, additional gross ( $₹ 5,922 \mathrm{ha}^{-1}$ ) and net return ( $₹ 4,642 \mathrm{ha}^{-1}$ ) in comparison to Farmers' practice. This resulted in realizing higher incremental cost benefit ratio (4.70) and benefit: cost ratio (3.43) compared to the Farmers' practice (3.29) during three years study period. This enhancement in grain yield and economics of chickpea under demonstrations clearly showed the impact of adoption of improved technology over farmers' practice in Humid South Eastern Plain Zone of Rajasthan.
\end{abstract}

Keywords: Chickpea, front line demonstrations, yield gap, economics

\section{Introduction}

Chickpea (Cicer arietinum L.) is the premier pulse crop of the Indian subcontinent. India is the largest chickpea producer as well as consumer in the world. In India, chickpea covers an acreage of 10.56 mha contributing $11.38 \mathrm{mt}$ of production with an average productivity of $1078 \mathrm{~kg} \mathrm{ha}^{-1}$ during 2017-18 (Anonymous, 2019). Chickpea production has gone up from 3.65 to $10.56 \mathrm{mt}$ from $1950-51$ to $2017-18$ and productivity steadily increased to $1078 \mathrm{~kg} \mathrm{ha}^{-1}$ from $482 \mathrm{~kg} \mathrm{ha}^{-1}$ (Anonymous, 2019). In India, the leading chickpea producing states are Madhya Pradesh, Maharashtra, Rajasthan, Karnataka, Andhra Pradesh and Uttar Pradesh. These six states, contribute 88.48 per cent of total chickpea production of India. The state

Article History

RECEIVED in $30^{\text {th }}$ April 2020 RECEIVED in revised form $02^{\text {nd }}$ June 2020 ACCEPTED in final form $16^{\text {th }}$ June 2020 
of Rajasthan has occupied an acreage of 1.57 million hectares with a production of $1.69 \mathrm{mt}$ and productivity of $1074 \mathrm{~kg} \mathrm{ha}^{-1}$ (Anonymous, 2019). There has been a major shift in the area of chickpea in the country. The expansion of irrigation facilities in northern India has laid to replacement of chickpea with wheat and mustard in larger area. As a result, the chickpea area reduced from 3.2 mha to 1.0 mha in northern states of the country. Chickpea is one of most important pulse crops of India due to its multiple functions in the traditional farming system, besides helping in the management of soil fertility with the ability to fix atmospheric nitrogen through root nodules. It is an important source of human food and animal feed. (Saxena and Singh, 1987; Ali and Kumar, 2009). Additionally, compared with animal protein, chickpea is the major and cheap source of protein especially for the vegetarian population (Singh et al., 2016).

The demonstration districts under the study viz; Kota covers acreage of 52,419 ha with the production of $77,531 \mathrm{t}$ and productivity of $1,510 \mathrm{~kg} \mathrm{ha}^{-1}$. Likewise, Bundi district produces $64,815 \mathrm{t}$ from an area of 50,597 ha and productivity of 1,280 $\mathrm{kg} \mathrm{ha}^{-1}$. Moreover, Baran district covers an area of 71,017 ha, and contributes $130,884 \mathrm{t}$ with the productivity of $1,840 \mathrm{~kg} \mathrm{ha}^{-1}$ (Anonymous, 2018). It clearly indicates that the productivity of chickpea in Kota, Bundi and Baran districts is comparatively higher than the state average yield $\left(1,070 \mathrm{~kg} \mathrm{ha}^{-1}\right)$. However, still it is low compared with production potential of the zone. This is primarily due to unavailability of suitable high yielding varieties as well as lack of improved agro-techniques, especially methods of sowing, weed management, balanced fertilization and proper insect pest management practices. During last five decades, chickpea has registered significant increase in production, which is primarily due to introduction of high yielding and disease resistant varieties and adoption of improved production technologies. Nevertheless, pulses production enhanced substantially during the last decade but continuing the pace of faster growth is a bigger challenge to the researchers, extension agencies and policy makers to fulfil the domestic demand within the country. The existing technology has the potential of doubling production without increasing area under chickpea as well as existing yield gap can be filled by the farmers adoption of the recommended package of practices (Reddy et al., 2007).

The productivity of chickpea can be further enhanced by adopting improved high yielding varieties and scientific crop management practices (Asiwal and Hussain, 2008 and Kumar et al., 2016). Thus, there is need to increase production and productivity of pulses in the country by more intensive interventions. Front line demonstration is the novel concept of the field demonstration with the focal objectives to demonstrate newly released high yielding varieties following improved agro-techniques at farmer's field. Improved agricultural technologies are the product of modern science which leads to ultimate sustainable production. Chickpea (Cicer arietinum) is established as major rabi crop in central part of India. In India, the gap analysis envisages and set aside alarms for bridging the extension gap through effective extension functionaries (Singh et al., 2013). Survey of technology adoption levels of package of practices in Rajasthan indicated that there was either lack of adoption or partial adoption of improved practices resulting in lower productivity levels as compared to potential yield levels recorded in the yield. Least use of improved varieties, higher seed rate, lack of seed treatment with chemical and bio-agents (Rhizobium, PSB), inadequate and imbalanced fertilizer use, lack of use of plant protection measures were some of the critical production factors contributed to the poor and stable yield.

To convince the chickpea growers on effectiveness of technology and to motivate them for adoption, laying out of demonstration at farmers own field is one of the proven methods. In view of the above facts, frontline demonstrations conducted to demonstrate the potentials of improved technology (IT) versus farmers' practices (FP) under real farm situations.

\section{Materials and Methods}

Under the investigation, a total of 160 Frontline demonstrations were organized on farmers' field at various locations viz; Ladpura, Singod, Digod tehsils of Kota; Keshoraipatan, Talera and Hindoli tehsils of Bundi and Atru, Chhabra, Chipabarod tehsils of Baran districts to demonstrate the impact of production technology on chickpea productivity over three years during rabi seasons starting from October 2007 to April 2008, October 2008 to April 2009 and October 2009 to April 2010. Before laying out the demonstrations at farmers' field, the composite soil samples were collected and analyzed to determine the physico-chemical properties of the investigation site. The soil of the demonstration field was neutral in soil $\mathrm{pH}$, non-saline in EC, medium (Kota, Bundi) to low (Baran) in organic carbon, low in available $\mathrm{N}$ and $\mathrm{Fe}$, medium in available $\mathrm{P}_{2} \mathrm{O}_{5}$ and $\mathrm{S}$, high in available $\mathrm{K}_{2} \mathrm{O}$ and $\mathrm{Zn}$ (Table 1 ). The soil texture was clay loam in all the demonstrations districts viz; Kota, Bundi and Baran. The selection of cultivators was done on the basis of Participatory Rural Appraisal (PRA). Further, so as to popularize the improved technology, the demonstrations were laid out on road side. Each frontline demonstration was laid out on 0.4 ha area and the adjacent 0.4 ha was considered as check (farmers' practice). The improved package of practices include short/medium duration improved varieties (GNG-469, GNG663), seed treatment with biofertilizers (Rhizobium and PSB culture), fungicides (Carbendazim $2 \mathrm{~g} \mathrm{~kg}^{-1}$ seed), application of recommended dose of fertilizer ( $40 \mathrm{~kg} \mathrm{~N}, 20 \mathrm{~kg} \mathrm{P}_{2} \mathrm{O}_{5}$ and $30 \mathrm{~kg} \mathrm{~S} \mathrm{ha}^{-1}$, respectively), weed management (pendimethalin 30 EC @ 1.0 litre a. i. ha ${ }^{-1}$ ) and pest management (One spray of acephate 75 SP @ $700 \mathrm{~g} \mathrm{ha}^{-1}$ ) at pod borer infestation. Half of the nitrogen and full amount of phosphorus and sulphur were applied as basal in the respective plots. The 


\begin{tabular}{lccc}
\hline \multicolumn{4}{l}{$\begin{array}{l}\text { Table 1: Physico-chemical characteristics of the demonstration } \\
\text { field }(0-30 \mathrm{~cm})\end{array}$} \\
\hline Soil parameters & Kota & Bundi & Baran \\
\hline $\mathrm{pH}$ & 7.20 & 7.24 & 7.34 \\
$\mathrm{EC}\left(\mathrm{dS} \mathrm{m} \mathrm{m}^{-1}\right)$ & 0.47 & 0.54 & 0.42 \\
Organic carbon (\%) & 0.57 & 0.51 & 0.42 \\
Bulk density $\left(\mathrm{Mg} \mathrm{m}^{-3}\right)$ & 1.24 & 1.21 & 1.28 \\
Available $\mathrm{N}\left(\mathrm{kg} \mathrm{ha}^{-1}\right)$ & 265 & 274 & 240 \\
Available $\mathrm{P}_{2} \mathrm{O}_{5}\left(\mathrm{~kg} \mathrm{ha}^{-1}\right)$ & 22.3 & 18.2 & 20.4 \\
Available $\mathrm{K}_{2} \mathrm{O}\left(\mathrm{kg} \mathrm{ha}^{-1}\right)$ & 320 & 294 & 310 \\
Available S $\left(\mathrm{mg} \mathrm{kg}^{-1}\right)$ & 14.6 & 11.4 & 12.8 \\
DTPA extractable Zn (mg & 1.97 & 1.94 & 2.09 \\
$\left.\mathrm{~kg}^{-1}\right)$ & & & \\
DTPA extractable Fe $(\mathrm{mg}$ & 3.25 & 3.31 & 3.10 \\
$\left.\mathrm{~kg}^{-1}\right)$ & & & \\
Soil texture & Clay & Clay & Clay \\
& loam & loam & loam \\
\hline
\end{tabular}

performance of chickpea under these demonstrations were compared with the farmers' practice which include $100 \mathrm{~kg}$ $\mathrm{ha}^{-1}$ self procured seed without seed treatment and no use of any fertilizers. The results were economically analyzed in terms of $\mathrm{B}: \mathrm{C}$ ratio and net returns to re-establish the viability. Maximum demonstrations were sown in the first fortnight of October. The yield and economics of data was obtained from 160 respondents from 15 selected villages for a period of three years. The yield data were collected from both the demonstration and farmers practice by random crop cutting methods and analyzed by using simple statistical tools. The Technology yield gap, extension yield gap and technology index (Samui et al., 2000) were calculated using following formulae given hereunder:

Percent increase in yield $=\left[\left(\right.\right.$ Demonstration yield $\left(\mathrm{kg} \mathrm{ha}^{-1}\right)$ Farmers' practice yield $\left(\mathrm{kg} \mathrm{ha}^{-1}\right) \div($ Farmers' practice yield ( $\mathrm{kg}$ $\left.\mathrm{ha}^{-1}\right) \mathrm{l} \times 100$

Technology yield gap $\left(\mathrm{kg} \mathrm{ha}^{-1}\right)=$ Potential yield $\left(\mathrm{kg} \mathrm{ha}^{-1}\right)$ Demonstration yield $\left(\mathrm{kg} \mathrm{ha}^{-1}\right)$

Extension yield gap $\left(\mathrm{kg} \mathrm{ha}^{-1}\right)=$ Demonstration yield $\left(\mathrm{kg} \mathrm{ha}^{-1}\right)-$ Farmers practice yield $\left(\mathrm{kg} \mathrm{ha}^{-1}\right)$

Technology index $(\%)=$ Potential yield $\left(\mathrm{kg} \mathrm{ha}^{-1}\right)$-Demonstration yield $\left(\mathrm{kg} \mathrm{ha}^{-1}\right) \div$ Potential yield $\left(\mathrm{kg} \mathrm{ha}^{-1}\right) \times 100$

Unlikely, eeconomics of the demonstrations under improved technology and farmers practice were recorded. Based on economics, additional cost, effective gain, additional returns, incremental B:C ratios were calculated. These economic parameters were analyzed using the formulae given below:

Additional cost $\left(₹ \mathrm{ha}^{-1}\right)=$ Demonstration cost $\left(₹ \mathrm{ha}^{-1}\right)$-Farmers' practice cost $\left(₹ \mathrm{ha}^{-1}\right)$
Additional returns $\left(₹ \mathrm{ha}^{-1}\right)=$ Demonstration returns $\left(₹ \mathrm{ha}^{-1}\right)$ -Farmers practice returns ( $₹ \mathrm{ha}^{-1}$ )

Effective gain $\left(₹ \mathrm{ha}^{-1}\right)=$ Additional returns $(₹$ ha-1 $)$-Additional cost (₹ ha-1)

Incremental B: $\mathrm{C}$ ratio $=$ Additional returns $\left(₹ \mathrm{ha}^{-1}\right) \div$ Additional cost (₹ ha-1)

\section{Results and Discussion}

\subsection{Technology interventions $\mathrm{v} / \mathrm{s}$ farmers practice}

Before initiation of the front line demonstrations at the farmers' field, participatory rural appraisal was undertaken. Based on this, the gap between farmer practices and improved technology of chickpea cultivation in Kota, Bundi and Baran districts of Rajasthan are presented in Table 2. Among different components, full gap was observed in the components viz; improved varieties, seed treatment, seed inoculation, fertilizer dose and weed management practices. Whereas, partial gap was observed for the components viz; spacing, irrigation and plant protection measures. However, no gap was found for the components field preparation and sowing method. These gaps noticed at the farmers field are ascribed to the slow pace of extension machineries, coupled with unreached public extension system, poor accessibility of advanced or improved agro-technologies especially among smallholder farmers and other vulnerable groups (Babu et al., 2013; Reddy and Swanson, 2006). Further, farmers used local or old varieties of low yield potential instead of newly released varieties with improper application of improved package technologies. Unavailability of good quality seed in time and lack of awareness were also the other important reasons for low productivity at farmer's field.

\subsection{Chickpea yield}

The results of three year (2007-08 to 2009-10) frontline demonstrations conducted on farmer's field under real farm conditions in Kota, Bundi and Baran districts of Rajasthan indicated that improved technology could lead to average grain yield levels in the range of 1773 to $1907 \mathrm{~kg} \mathrm{ha}^{-1}$ as compared to 1529 to $1649 \mathrm{~kg} \mathrm{ha}^{-1}$ under farmers' practice. Average yield of 160 demonstrations worked out to $1832 \mathrm{~kg}$ $\mathrm{ha}^{-1}$ from improved technology where as the average yield obtained in case of farmers' practice was $1600 \mathrm{~kg} \mathrm{ha}^{-1}$. These results reveal that the adoption of improved production technology of chickpea cultivation enhanced average yield by $14.72 \%$ (Table 3 ) over farmers practice. This results indicated that higher average grain yield in demonstration plots compare to farmers' practice ascribed to the knowledge and adoption of improved technologies i. e. suitable high yielding varieties with more potential yield such as GNG-469 and GNG-663, timely sowing, seed treatment with fungicides and biofertilizers (Rhizobium PSB culture), use of balanced fertilization, timely weed management and need based plant protection measures. Prajapat et al. (2016) also reported 


\begin{tabular}{|c|c|c|c|c|}
\hline $\begin{array}{l}\text { Sl. } \\
\text { No. }\end{array}$ & Component & Technological intervention & Farmer practice & Gap \\
\hline 1. & Field preparation & Three ploughing & Three ploughing & Nil \\
\hline 2. & Variety & GNG-469, GNG-663 & Old mix seed & Full \\
\hline 3. & Seed rate & $80 \mathrm{~kg} \mathrm{ha}^{-1}$ & $100 \mathrm{~kg} \mathrm{ha}^{-1}$ & Higher seed rate \\
\hline 4. & Seed treatment & Carbendazim @2 $\mathrm{g} \mathrm{kg}^{-1}$ of seed & No Seed treatment & Full \\
\hline 5. & Seed inoculation & $\begin{array}{l}\text { Rhizobium and PSB culture@10 } \mathrm{kg}^{-1} \\
\text { of seed }\end{array}$ & No seed inoculation & Full \\
\hline 6. & Sowing method & Line sowing & Line sowing & Nil \\
\hline 7. & Spacing & $30 \times 10 \mathrm{~cm}^{2}$ & $22.5 \times 10 \mathrm{~cm}^{2}$ & Partial \\
\hline 8. & Fertilizer dose & $\mathrm{N}-\mathrm{P}_{2} \mathrm{O}_{5}-\mathrm{K}_{2} \mathrm{O}-\mathrm{S} ; 20-40-0-30 \mathrm{~kg} \mathrm{ha}^{-1}$ & No use & Full \\
\hline 9. & Weed management & $\begin{array}{l}\text { Pre emergence application of Pendi- } \\
\text { methalin } 30 \text { EC @ } 1.0 \mathrm{~kg} \text { a.i. ha }{ }^{-1} \text { and } \\
\text { one hand weeding }\end{array}$ & No weeding & Full \\
\hline 10. & Irrigation & $\begin{array}{l}\text { Two irrigation at pre flowering stage } \\
\text { and pod development stage }\end{array}$ & One irrigation & Partial \\
\hline 11. & Plant protection measures & $\begin{array}{l}\text { Need based insecticide spray with } \\
\text { proper dose and time }\end{array}$ & $\begin{array}{l}\text { Use of insecticide without } \\
\text { knowledge and with incor- } \\
\text { rect dose of insecticide }\end{array}$ & Partial \\
\hline
\end{tabular}

Table 3: Productivity, technology yield gap, extension yield gap and technology index of chickpea front line demonstrations in Rajasthan

\begin{tabular}{|c|c|c|c|c|c|c|c|c|c|}
\hline \multirow[t]{2}{*}{ Year } & \multirow[t]{2}{*}{$\begin{array}{l}\text { No. of dem- } \\
\text { onstrations }\end{array}$} & \multirow[t]{2}{*}{$\begin{array}{l}\text { Area } \\
\text { (ha) }\end{array}$} & \multirow[t]{2}{*}{ Variety } & \multicolumn{2}{|c|}{$\begin{array}{l}\text { Grain yield } \\
\left(\mathrm{kg} \mathrm{ha}^{-1}\right)\end{array}$} & \multirow{2}{*}{$\begin{array}{c}\% \text { increase } \\
\text { in yield } \\
\text { over FP }\end{array}$} & \multirow{2}{*}{$\begin{array}{c}\text { Technology } \\
\text { yield gap (kg } \\
\text { ha }^{-1} \text { ) }\end{array}$} & \multirow{2}{*}{$\begin{array}{l}\text { Extension } \\
\text { yield gap } \\
\left(\mathrm{kg} \mathrm{ha}^{-1}\right)\end{array}$} & \multirow{2}{*}{$\begin{array}{c}\text { Technol- } \\
\text { ogy index } \\
(\%)\end{array}$} \\
\hline & & & & IT & FP & & & & \\
\hline 2007-08 & 75 & 62.5 & GNG-663 & 1907 & 1623 & 17.74 & 493 & 284 & 9.19 \\
\hline 2008-09 & 50 & 25.0 & GNG-469 & 1815 & 1649 & 10.20 & 585 & 166 & 13.57 \\
\hline $2009-10$ & 35 & 17.5 & GNG-469 & 1773 & 1529 & 16.23 & 627 & 244 & 15.57 \\
\hline Total & 160 & 105.0 & Average & 1832 & 1600 & 14.72 & 568 & 231 & 12.78 \\
\hline
\end{tabular}

IT= Improved technology; FP=Farmers practice (check)

yield enhancement, greater yield attributing characters and better root traits of chickpea due to application of recommended dose of fertilizers and biofertilizers. Likewise, yield enhancement in different chickpea varieties ascribed to phosphorus addition in vertisols (Neenu et al., 2014). Moreover, the present findings are in close conformity with the results reported by Dayanand et al. (2014), Mishra and Khare (2017), Tiwari and Tripathi (2014), Kaur et al. (2019)

\subsection{Yield gap analysis}

The front line demonstrations conducted under the study reveals that the technology yield gap was 493, 585 and 627 $\mathrm{kg} \mathrm{ha}^{-1}$ during 2007-08, 2008-09 and 2009-10, respectively (Table 3). On an average, technology yield gap during three years of study under front line demonstration was $568 \mathrm{~kg} \mathrm{ha}^{-1}$.
Technology yield gap variations over the years led to the variation in local climatic conditions, soil fertility status of fields and agricultural practices. Unlike technology yield gap, extension yield gap were also recorded to the tune of 166 to $284 \mathrm{~kg} \mathrm{ha}^{-1}$ over the years. On an average, the extension yield gap was recorded to the level of $231 \mathrm{~kg} \mathrm{ha}^{-1}$ (Table 3). The extension yield gap observed under the study emphasized the need to educate the farmers for dissemination of technologies and bridge gap through advanced extension strategies viz; frontline demonstrations, field days, farmers' scientist interactions, trainings, on farm trainings, Kisan gosthi etc. The technology index, another effective tool for analysis of yield gap under the investigation varied from 9.19 to $15.57 \%$ (Table 3). On an average technology index was recorded $12.78 \%$. Lower the value of technology index, greater is the feasibility 
of technology. This shows the efficacy of overt performance of scientific interventions or technologies demonstrated at farmer's field. As a result, this will increase the yield of chickpea under the existing conditions of agro-ecological region of humid south eastern plain zone of Rajasthan. These findings corroborate the findings as reported by Dwivedi et al. (2014), Kumar (2014), Kumar et al. (2016), Praharaj et al. (2015), and Meena (2017).

\subsection{Economics}

Economics, an important parameter to reject or accept the technology was estimated under the study. The economics of the improved technology over farmers practice were calculated depending on the prevailing market prices of the inputs and outputs for the particular year (Table 4). It was observed that the cost of cultivation of chickpea varied from ₹ 12,255 to ₹ 12,880 ha $^{-1}$ with an average of ₹ $12,552 \mathrm{ha}^{-1}$. Under improved technologies, as against in farmers practices the cost of cultivation of chickpea ranges from ₹ $10,943 \mathrm{ha}^{-1}$ to ₹ $11,661 \mathrm{ha}^{-1}$ with an average of ₹ $11,272 \mathrm{ha}^{-1}$. Under the present investigation, improved technology fetched higher net returns to the tune of ₹ $28,534 \mathrm{ha}^{-1}$ to ₹ $31,347 \mathrm{ha}^{-1}$ with the mean of three yeas was ₹ $30,087 \mathrm{ha}^{-1}$. However, under farmers practices the net returns ranged to the tune of ₹ $24,217 \mathrm{ha}^{-1}$ to ₹ $26,106 \mathrm{ha}^{-1}$ over the years and its average value fetched to ₹ $25,445 \mathrm{ha}^{-1}$. Under the study, average additional gross returns of ₹ 5,922 ha-1 and additional net returns of ₹ 4,642 ha-1 were recorded with the incremental cost benefit ratio of 4.70. As a result of demonstrations, effective gain recorded from ₹ 3,005 ha ${ }^{-1}$ to ₹ $3,932 \mathrm{ha}^{-1}$ with an average over the years to the tune of ₹ $3,362 \mathrm{ha}^{-1}$. Given the economic analysis in terms of benefit cost ratio, it was fetched 3.52 (2007-08), 3.44 (2008-09) and 3.34 (2009-10) following improved technology interventions at farmers field. On the same situation following farmers' practice, fetched lower benefit cost ratio to the tune of 3.35 (2007-08), 3.29 (2008-09) and 3.23 (2009-10). On an average,

\begin{tabular}{|c|c|c|c|c|c|c|c|c|c|c|c|c|c|}
\hline \multirow[t]{2}{*}{ Year } & \multicolumn{2}{|c|}{$\begin{array}{c}\text { Cost of cultiva- } \\
\text { tion (₹ ha-1) }\end{array}$} & \multicolumn{2}{|c|}{$\begin{array}{l}\text { Gross return } \\
\left(₹ \text { ha }^{-1}\right)\end{array}$} & \multicolumn{2}{|c|}{$\begin{array}{l}\text { Net return } \\
\left(₹ \mathrm{ha}^{-1}\right)\end{array}$} & \multirow[t]{2}{*}{ ACFP } & \multirow[t]{2}{*}{ AGROFP } & \multirow[t]{2}{*}{ AROFP } & \multirow[t]{2}{*}{ EG } & \multirow[t]{2}{*}{ ICBR } & \multicolumn{2}{|c|}{ B:C Ratio } \\
\hline & IT & FP & IT & FP & IT & FP & & & & & & IT & FP \\
\hline 2007-08 & 12,522 & 11,213 & 43,869 & 37,319 & 31,347 & 26,106 & 1,309 & 6,550 & 5,241 & 3,932 & 5.14 & 3.52 & 3.35 \\
\hline 2008-09 & 12,880 & 11,661 & 43,260 & 37,674 & 30,380 & 26,013 & 1,219 & 5,587 & 4,367 & 3,148 & 4.54 & 3.44 & 3.29 \\
\hline $2009-10$ & 12,255 & 10,943 & 40,789 & 35,160 & 28,534 & 24,217 & 1,312 & 5,629 & 4,317 & 3,005 & 4.41 & 3.34 & 3.23 \\
\hline Average & 12,552 & 11,272 & 42,639 & 36,718 & 30,087 & 25,445 & 1,280 & 5,922 & 4,642 & 3,362 & 4.70 & 3.43 & 3.29 \\
\hline
\end{tabular}

IT= Improved technology; FP=Farmers' practice (check); 1 US\$= ₹ 40.24, 45.91 and 47.41 during 2008, 2009 and 2010, respectively, ACFP: Additional cost over FP (₹ ha- ${ }^{-1}$ ); AGROFP: Additional gross return over FP ( $₹$ ha $\left.^{-1}\right)$; AROFP: Additional net return over FP ( $₹$ ha $\left.{ }^{-1}\right)$; EG: Effective gain ( $₹$ ha $\left.^{-1}\right)$

benefit cost ratio under improved technology and farmers' practice was recorded 3.43. and 3.29, respectively. The higher benefit cost ratio in improved technology was due to the higher yield obtained under improved technology as compared to farmers' practice. Hence higher benefit cost ratio proved the economic viability of the technology interventions and convinced the farmers on the utility of improved technologies. Similar economic benefits owing to adoption of improved technology interventions were also reported by Dwivedi et al. (2014), Kumar (2014), Gorfad, et al. (2016), Singh (2016) and Parmar et al. (2017).

\section{Conclusion}

Improved technologies are more productive and remunerative compared with farmers' practices. On an average, higher gross returns ( $₹ 42,639 \mathrm{ha}^{-1}$ ), net returns ( $\left.₹ 30,087 \mathrm{ha}^{-1}\right)$, effective gain (₹ 3,362 ha-1), ICBR (4.70) and benefit-cost ratio (3.43) were fetched under improved technologies over farmers' practice. Thus, adoption of improved technology has a longterm impact on crop productivity and profitability in chickpea over farmers' practice.

\section{Acknowledgement}

The financial support to meet the expenses towards frontline demonstrations by Department of Agricultural \& Farmers Welfare, Government of India through its nodal agency ICAR- Indian Institute of Pulses Research, Kanpur is gratefully acknowledged.

\section{References}

Ali, M., Kumar, S., 2009. Major technological advances in pulses: Indian scenario. In: Ali, M., Kumar, S. (Eds.), Milestones in Food Legumes Research. Indian Institute of Pulses Research, Kanpur, 1-20.

Anonymous, 2018. Department of Agriculture Cooperation \& Farmers Welfare, Directorate of Economics and Statistics, 2017-18, Government of India, Third advance estimate. Available from: https://aps.dac.gov.in/APY/ Public_Report1.aspx.

Anonymous, 2019. Department of Agriculture Cooperation \& Farmers Welfare, Directorate of Economics and Statistics, 2018-19, Government of India, Third advance estimate. Available from: https://eands.dacnet.nic.in/. 
Asiwal, B.L., Hussain, A., 2008. Demonstration- An Effective Technology for Increasing the Productivity of Gram. Rajasthan Journal of Extension Education 16, 221-223.

Babu, S.C., Joshi, P.K., Glendenning, C.J., Asenso-Okyere, K., Sulaiman, V.R., 2013. The State of Agricultural Extension Reforms in India: Strategic Priorities and Policy Options. Agricultural Economics Research Review 26(2), 159-72.

Dayanand, Verma, R.K., Mehta, S.M., 2014. Assessment of Technology Gap and Productivity Gain through Front line Demonstration in Chickpea. Legume Research-An International Journal 37(4), 430-433.

Dwivedi, A.P., Mishra, A., Singh, S.K., Singh, S.R.K., Singh, M., 2014. Yield gap analysis of chickpea through front line demonstration in different agro-climatic zones of MP and Chhatishgarh. Journal of Food Legumes 27(1), 60-63.

Gorfad, P.S., Baraiya, K.P., Parakhia, A.M., 2016. Impact of front line demonstration (FLDs) of pulse crops in improved technology transfer. International Journal of Agriculture Sciences 8(13), 1228-1229.

Kaur, J., Singh, V., Aulakh, G.S., Raina, D., 2019. Assessment of front line demonstrations on chickpea in Ferozepur district of Punjab. Journal of Food Legumes 32(1), 49-52.

Kumar, R., 2014. Assessment of technology gap and productivity gain through crop technology demonstration in chickpea. Indian Journal of Agricultural Research 48(2), 162-164.

Kumar, M., Kumar, A., Kumar, A., Kumari, H., 2016. Evaluation of Farmers Saved Seed of Green Gram and Chickpea in Munger District of Bihar. International Journal of Bioresource and Stress Management, 7(4) Special, 773-777.

Meena, M.L., 2017. Effect of front line demonstrations of chickpea Cv. RSG-888 on farmers field in rainfed condition of Rajasthan, India. Asian Journal of Agriculture Extension, Economics \& Sociology 18 (2), 1-7.

Mishra, P.K., Khare, Y.R., 2017. Impact of front line demonstration on yield and profitability of chickpea (Cicer arietinum) in Sagar district of Bundelkhand Region of Madhya Pradesh, India. Plant Archives 17(1), 463-466.

Neenu, S., Ramesh, K., Ramana, S., Biswas, A.K., Rao, A.S., 2014. Growth and Yield of Different Varieties of Chickpea (Cicer arietinum L.) as Influenced by the Phosphorus Nutrition under Rainfed Conditions on Vertisols. International Journal of Bio-resource and Stress Management 5(1), 053-057.

Parmar, M.R., Choudhary, S., Wankhede, A., Swarnakar, V.K.,
2017. Impact of Frontline Demonstration in Adoption of Chickpea Production Technology by the Farmers of Sehore District, Madhya Pradesh, India. Journal of Agriculture and Veterinary Science 10(6) 1, 76-80.

Praharaj, C.S., Kumar, R., Akram, M., Jha, U.C., Singh, U., Kumar, N., Singh, S.S., 2015. Dissemination of pulses production technologies for enhancing profitability of farmers in Uttar Pradesh. Journal of Food Legumes 28(2), 157-161.

Prajapat, K., Vyas, A.K., Dhar, S., 2016. Root Growth and Productivity of Wheat, Chickpea and Potato as Influenced by Nutrient Management Practices. International Journal of Bio-resource and Stress Management 7(1), 052-059.

Reddy, A.A., Mature, V.C., Yadav, M., Yadav, S.S., 2007. Profitability in Chickpea cultivation. In: Yadav, S.S., Redden, B., Chen, W., Sharma, B. (Ed.), The Chickpea Breeding and Management. Wallingford, Oxon, UK- CAB International, 292-321.

Reddy, M.N., Swanson, B., 2006. Strategy for up-scaling the ATMA model in India, In: Vreyens, J.R. (Ed.), In: Proceedings of the Association for International Agricultural and Extension Education, AIAEE $22^{\text {nd }}$ Annual Conference, Clearwater Beach, Florida, USA.

Samui, S.K., Maitra, S., Roy, D.K., Mondal, A.K., Saha, D., 2000. Evaluation of front line demonstration on groundnut (Arachis hypogea L.). Journal of the Indian Society of Coastal Agriculture Research 18(2), 180-183.

Saxena, M.C., Singh, K.B., 1987. The chickpea. C.A.B. International, Wallingford, United Kingdom, 409. ISBN 0851985718.

Singh, U., Praharaj, C.S., Singh, S.S., Singh, N.P., 2016. Biofortification of food crops. New Delhi, India, Springer

Singh, K.M., Meena, M.S., Burton, S., 2013. Extension in India by Public Sector Institutions: An Overview. Available from: https://ssrn.com/abstract=2315457 or http:// dx.doi.org/ 10.2139/ssrn.2315457.

Singh, R., 2016. Productivity Enhancement of Chickpea (Cicer arietinum) through Improved Production Technologies on Farmer's Field. Indian Journal of Agricultural Sciences 86(10), 1357-60.

Tiwari, B.K., Tripathi, P.N., 2014. Yield gap analysis of chickpea (Cicer arietinum) through front line demonstration on farmers' fields. Journal of Rural and Agricultural Research 14(1), 5-8. 